\title{
An Insight into Antibacterial and Anticancer Activity of Homo and Hetero Binuclear Schiff Base Complexes
}

\author{
BHOOPATHY PARASURAMAN', \\ JAYALAKSHMI RAJENDRAN ${ }^{1}$ and RAJAVEL RANGAPPAN ${ }^{*}$ \\ 'Department of Chemistry, Periyar University, Salem-636 011, Tamilnadu, India. \\ ${ }^{\star}$ Corresponding Author E-mail address: drrajavelpu@gmail.com \\ http://dx.doi.org/10.13005/ojc/330321
}

(Received: April 10, 2017; Accepted: May 09, 2017)

\begin{abstract}
Mononuclear complex has been used as a building block in the synthesis of homo/hetero binuclear complexes. The complex behaves as a potential metallo-ligand. Its reaction with different metal salts ( $\mathrm{Ni} \& \mathrm{Cu}$ ) lead to the formation of binuclear complexes. The homo and hetero binuclear oxygen bridged $\mathrm{Cu}(\mathrm{II})$ and $\mathrm{Ni}(\mathrm{II})$ complexes had been synthesized from the Schiff base ligand derived from 4-chloro-o-phenylenediamine and 3,5-dichloro-2-hydroxyacetophenone. The synthesized complexes have been characterized with the support of more than a few standard physicochemical techniques such as elemental analysis, spectroscopic, thermal, cyclic voltammetry and magnetic moment studies. Spectral analysis exhibits square planer geometry for $\mathrm{Cu}$ (II) \& Ni(II) mono and binuclear complexes. The antimicrobial results indicate that the homo-binuclear copper complex exhibit more activity than the other mono and binuclear complexes. The Schiff base and their complexes have been screened for their anticancer activity using MCF7 cell line.
\end{abstract}

Keywords: 4-chloro-o-phenylenediamine, thermal, antibacterial, MCF7, square planar.

\section{INTRODUCTION}

The interaction of organic / inorganic ligands with the metal centers is one of the most active research areas in inorganic chemistry. Coordination chemistry includes different types of coordination complexes applicable in a wide diversity of fields such as, catalysis, bioinorganic chemistry, medicine, ceramics, material science and toxicology. However, significant increasing drug resistance has limited the clinical applications of metal compounds activity and biological applications including antimicrobial, insecticidal, anti-HIV, antitumor and in vitro-cytotoxic activities as well as DNA binders. Transition metal ions such as $\mathrm{Pt}(\mathrm{II}), \mathrm{Cd}(\mathrm{II}), \mathrm{Hg}(\mathrm{II})$ and $\mathrm{Pb}$ (II) are recognized as highly toxic, which makes their presence in environmental waters or soils disagreeable. Even at very low concentrations such metals produces toxic effects in plants and animals. Such environmental issues can be overcome by the use of biologically-essential elements such as $\mathrm{Cu}$ (II) and $\mathrm{Ni}(\mathrm{II}){ }^{1-3}$. Although the pharmaceutical industry 
has witnessed so many drugs all these years, there is still a need for a most potential drug with minimum side effects. Cancer is a major threat in front of our mankind today and is one of the primary concerns of the field of medicinal inorganic chemistry. When cisplatin was accepted as a chemotherapeutic drug, it revolutionized the therapeutic industry. This paved way for the construction of novel compounds by metal-ligand bonding. Platinum-based complexes had been a research focus for many years, but now there are more explorations in non-platinum based drugs too ${ }^{4-7}$. The synthesis of symmetrical and unsymmetrical binuclear $\mathrm{Cu}(\mathrm{II})$ and $\mathrm{Ni}$ (II) complexes has gained more attention in recent years. Among the variety of methodologies applied to synthesize polynuclear metal complexes, the use of mononuclear complexes as ligands, is very useful and successful ${ }^{8,9}$. Based on this, in the present work, the main focus is the synthesis of homo and hetero binuclear symmetrical and unsymmetrical $\mathrm{Cu}$ (II) \& $\mathrm{Ni}(\mathrm{II})$ complexes with a new Schiff base ligand derived from 4 - chloro-o-phenylenediamine and 3,5-dichloro-2-hydroxyacetophenone.

\section{EXPERIMENTAL METHODS}

\section{Materials}

All chemicals used were of the analytical reagent grade $(A R)$ and of the highest purity available. They included 3,5-dichloro-2-hydroxyacetophenone (sigma) and 4-chloro-o-phenylenediamine (sigma), $\mathrm{NiCl}_{2} \cdot 6 \mathrm{H}_{2} \mathrm{O}(\mathrm{BDH}), \mathrm{CuCl}_{2}$ (sigma). Organic solvents used includes absolute ethyl alcohol, diethylether, chloroform, diethylamine and dimethyl formamide (DMF).

\section{Physical measurements}

UV-vis spectra of the metal complexes in ethanol were recorded on a Shimadzu UV3101PC UV-vis-NIR scanning spectrophotometer between 200 and $800 \mathrm{~nm}$. IR spectra of the ligands and their metal complexes, as $\mathrm{KBr}$ discs, were<smiles>CC(=Nc1ccc(Cl)cc1N=C(C)c1cc(Cl)cc(Cl)c1O)c1cc(Cl)cc(Cl)c1O</smiles>

Scheme1: Synthesis of ligand<smiles>CC(=Nc1ccc(Cl)cc1N=C(C)c1cc(Cl)cc(Cl)c1O)c1cc(Cl)cc(Cl)c1O</smiles>

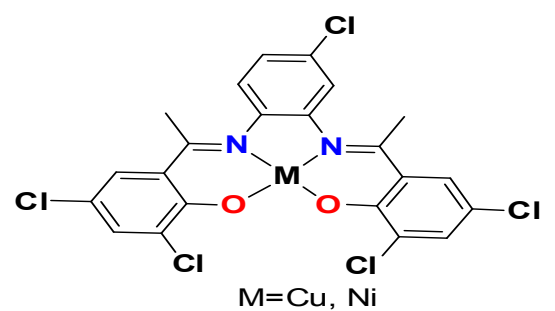

Scheme 2: Synthesis of mononuclear complexes

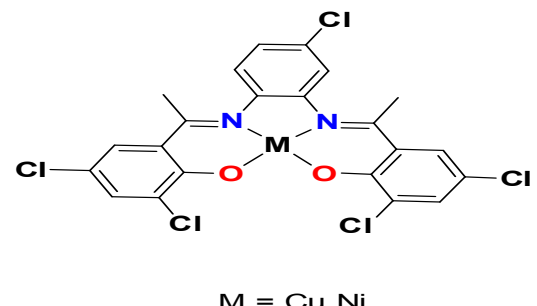

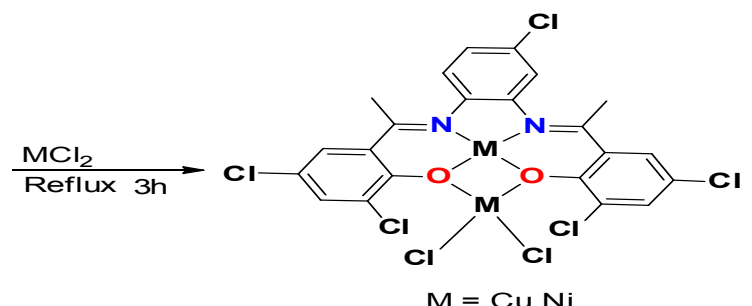

Scheme3: Synthesis of homo binuclear complexes 
recorded on a FT-IR 1650 Shimadzu spectrometer in the region $4000-400 \mathrm{~cm}^{-1}$. ${ }^{1} \mathrm{HNMR}$ spectra of the ligand and its complexes, were recorded in $\mathrm{CDCl}_{3}$ on a $500 \mathrm{MHz}$ Bruker spectrometer at room temperature using TMS as internal standard. Electrochemical experiments were performed with a $\mathrm{CHI} 760$ electrochemical analyzer, in single compartmental cells using tetrabutylammonium perchlorate (TBAP) as a supporting electrolyte. Thermal studies of the synthesized compounds were carried out in the Shimadzu, DTG-60, heating rate 20 degrees/min 20-800 pC range under $\mathrm{N}_{2}$ atmosphere. The EPR spectrum was recorded on an X-band in the solid state using Bruker EMX Plus with Microwave Frequency, $9.865832 \mathrm{GHz}$ at room temperature in DMSO of liquid nitrogen using DPPH

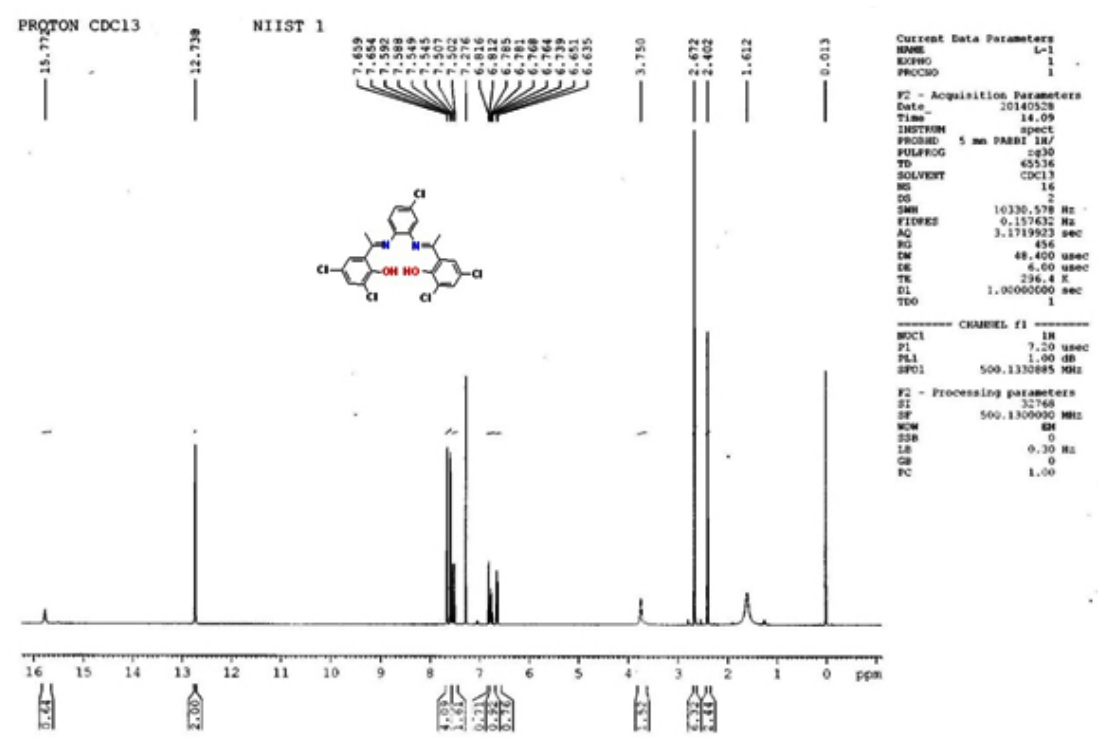

Fig. 1: ${ }^{1} \mathrm{H}$ NMR spectrum of Schiff base ligand

Table 1: Analytical data of the Schiff base ligand and its Complexes

\begin{tabular}{|c|c|c|c|c|c|c|c|c|c|c|c|}
\hline \multirow{2}{*}{$\begin{array}{l}\text { Comp- } \\
\text { ounds }\end{array}$} & \multirow{2}{*}{$\begin{array}{l}\text { Molecular } \\
\text { Formula }\end{array}$} & \multirow{2}{*}{$\begin{array}{l}\text { Yield } \\
\%\end{array}$} & \multirow{2}{*}{ Color } & \multirow{2}{*}{$\begin{array}{r}\text { M.Pt } \\
\left({ }^{\circ} \mathrm{C}\right)\end{array}$} & \multicolumn{6}{|c|}{ Calculated (Found) \% } & \multirow{2}{*}{$\begin{array}{c}\Delta \mathrm{m} \\
\left(\mathrm{ohm}^{-1}\right. \\
\mathrm{cm}^{2} \\
\mathrm{~mol}^{-1} \text { ) }\end{array}$} \\
\hline & & & & & C & H & $\mathbf{N}$ & $\mathrm{Cl}$ & $\mathrm{Cu}$ & $\mathrm{Ni}$ & \\
\hline L & $\begin{array}{c}\mathrm{C}_{22} \mathrm{H}_{15} \mathrm{Cl}_{5} \\
\mathrm{~N}_{2} \mathrm{O}_{2}\end{array}$ & 80 & Brown & $\begin{array}{c}102 \\
-105\end{array}$ & $\begin{array}{c}51.15 \\
(50.04)\end{array}$ & $\begin{array}{c}2.93 \\
(2.34)\end{array}$ & $\begin{array}{c}5.42 \\
(5.21)\end{array}$ & $\begin{array}{c}34.31 \\
(34.12)\end{array}$ & - & - & - \\
\hline CuL & $\begin{array}{l}\mathrm{CuC}_{22} \mathrm{H}_{13} \\
\mathrm{Cl}_{5} \mathrm{~N}_{2} \mathrm{O}_{2}\end{array}$ & 70 & $\begin{array}{l}\text { Bluish } \\
\text { brown }\end{array}$ & $>250$ & $\begin{array}{c}45.70 \\
(44.14)\end{array}$ & $\begin{array}{c}2.27 \\
(2.17)\end{array}$ & $\begin{array}{c}4.85 \\
(4.62)\end{array}$ & $\begin{array}{c}30.66 \\
(30.13)\end{array}$ & $\begin{array}{c}10.99 \\
(10.37)\end{array}$ & - & 14.84 \\
\hline NiL & $\begin{array}{l}\mathrm{NiC}_{22} \mathrm{H}_{13} \\
\mathrm{Cl}_{5} \mathrm{~N}_{2} \mathrm{O}_{2}\end{array}$ & 68 & $\begin{array}{c}\text { Greenish } \\
\text { brown }\end{array}$ & $>250$ & $\begin{array}{c}46.09 \\
(45.54)\end{array}$ & $\begin{array}{c}2.29 \\
(2.18)\end{array}$ & $\begin{array}{c}4.89 \\
(4.77)\end{array}$ & $\begin{array}{c}30.92 \\
(30.26)\end{array}$ & - & $\begin{array}{c}10.24 \\
(10.05)\end{array}$ & 14.58 \\
\hline $\mathrm{Cu}_{2} \mathrm{LCl}_{2}$ & $\begin{array}{c}\mathrm{Cu}_{2} \mathrm{C}_{22} \mathrm{H}_{13} \\
\mathrm{Cl}_{7} \mathrm{~N}_{2} \mathrm{O}_{2}\end{array}$ & 70 & $\begin{array}{l}\text { Dark } \\
\text { blue }\end{array}$ & $>250$ & $\begin{array}{c}37.08 \\
(36.78)\end{array}$ & $\begin{array}{c}1.84 \\
(1.79)\end{array}$ & $\begin{array}{c}3.93 \\
(3.84)\end{array}$ & $\begin{array}{c}34.83 \\
(34.08)\end{array}$ & $\begin{array}{c}17.83 \\
(17.62)\end{array}$ & - & 14.52 \\
\hline $\mathrm{Ni}_{2} \mathrm{LCl}_{2}$ & $\begin{array}{c}\mathrm{Ni}_{2} \mathrm{C}_{22} \mathrm{H}_{13} \\
\mathrm{Cl}_{7} \mathrm{~N}_{2} \mathrm{O}_{2}\end{array}$ & 67 & $\begin{array}{c}\text { Greenish } \\
\text { brown }\end{array}$ & $>250$ & $\begin{array}{c}37.59 \\
(38.85)\end{array}$ & $\begin{array}{c}1.86 \\
(1.81)\end{array}$ & $\begin{array}{c}3.99 \\
(3.92)\end{array}$ & $\begin{array}{c}35.31 \\
(34.80)\end{array}$ & - & $\begin{array}{c}16.70 \\
(16.56)\end{array}$ & 13.65 \\
\hline $\mathrm{CuNiLCl}_{2}$ & $\begin{array}{c}\mathrm{CuNiC}_{22} \mathrm{H}_{13} \\
\mathrm{Cl}_{7} \mathrm{~N}_{2} \mathrm{O}_{2}\end{array}$ & 72 & $\begin{array}{l}\text { Greenish } \\
\text { blue }\end{array}$ & $>250$ & $\begin{array}{c}37.33 \\
(36.81)\end{array}$ & $\begin{array}{c}1.85 \\
(1.82)\end{array}$ & $\begin{array}{c}3.96 \\
(3.92)\end{array}$ & $\begin{array}{c}35.06 \\
(34.75)\end{array}$ & $\begin{array}{c}8.98 \\
(8.86)\end{array}$ & $\begin{array}{c}8.29 \\
(8.17)\end{array}$ & 14.45 \\
\hline $\mathrm{NiCuLCl}_{2}$ & $\begin{array}{c}\mathrm{NiCuC}_{22} \mathrm{H}_{13} \\
\mathrm{Cl}_{7} \mathrm{~N}_{2} \mathrm{O}_{2}\end{array}$ & 70 & $\begin{array}{l}\text { Dark } \\
\text { green }\end{array}$ & $>250$ & $\begin{array}{c}37.33 \\
(36.64)\end{array}$ & $\begin{array}{c}1.82 \\
(1.78)\end{array}$ & $\begin{array}{c}3.96 \\
(3.93)\end{array}$ & $\begin{array}{c}35.06 \\
(34.72)\end{array}$ & $\begin{array}{c}8.98 \\
(8.81)\end{array}$ & $\begin{array}{c}8.29 \\
(8.12)\end{array}$ & 13.64 \\
\hline
\end{tabular}


free radical. Molar conductivity of $10^{-3} \mathrm{M}$ solutions of the complexes in ethanol was measured on the ELICO CM 185 conductivity Bridge.

\section{Synthetic methodology of Schiff base ligand and its mono and binuclear complexes Synthesis of ligand}

The ligand was prepared by adding an ethanolic solution (20 mL) of 3,5-dichloro-2hydroxyacetophenone $(0.4101 \mathrm{~g} ; 2 \mathrm{mmol})$ to an ethanolic solution of 4-chloro-o-phenylenediamine $(0.1426 \mathrm{~g} ; 1 \mathrm{mmol})$ with constant stirring followed by refluxion (3h). A brown solid was formed on cooling the solution slowly to room temperature and the precipitate was collected by filtration, washed with ethanol, then diethyl ether, and finally air-dried. The yield was $80 \%{ }^{10}$.

\section{Synthesis route of mononuclear Schiff base metal complexes}

Mononuclear $\mathrm{Cu}(\mathrm{II})$ complex

The solution of copper(II) acetate mono hydrate $(0.1997 \mathrm{~g} ; 1 \mathrm{mmol})$ in $20 \mathrm{~mL}$ ethanol was added drop wise to a solution of ligand $(0.5167 \mathrm{~g})$ in ethanol $(20 \mathrm{~mL})$ with constant stirring. The mixture was gently heated under reflux for $3 \mathrm{~h} .{ }^{11}$. After refluxing, the resulting solution was kept undisturbed for slow evaporation of the solvent. After four days, the bluish brown colored complex was filtered, washed thoroughly with ethanol and dried in a vacuum.

\section{Mononuclear $\mathrm{Ni}(\mathrm{II})$ complex}

Mononuclear $\mathrm{Ni}(\mathrm{II})$ complex was prepared by addition of an ethanolic solution $(20 \mathrm{~mL})$ of nickel (II) acetate tetrahydrate $(0.2488 \mathrm{~g} ; 1 \mathrm{mmol})$ to a solution of ligand $(0.5167 \mathrm{~g})$ in ethanol $(20 \mathrm{~mL})$ drop by drop with constant stirring. The mixture was gently heated under reflux for $3 \mathrm{~h} .{ }^{11}$, which resulted in a rapid change of color from brown to greenish brown powder. The greenish brown colored complex was filtered, washed thoroughly with ethanol and dried in a vacuum.

\section{Synthetic route of homo binuclear Schiff base metal complexes}

Homo binuclear $\mathrm{Cu}$ (II) complex

The homo binuclear copper(II) complex was synthesized by slow addition of $20 \mathrm{ml}$ ethanolic solution of anhydrous copper (II) chloride (0.1346g; $1 \mathrm{mmol})$ to $20 \mathrm{ml}$ ethanolic solution of mononuclear $\mathrm{Cu}$ (II) complex $(0.5781 \mathrm{~g} ; 1 \mathrm{mmol})$. The resulting mixture was heated under reflux for $3 \mathrm{hrs}{ }^{12,13}$. After refluxing, the resulting solution was filtered and the filtrate was left undisturbed for slow evaporation of the solvent. After five days, the dark blue coloured complex was obtained.

\section{Homo binuclear $\mathrm{Ni}(\mathrm{II})$ complex}

The homo binuclear nickel(II) complex was synthesized by slow addition of $20 \mathrm{ml}$ ethanolic solution of Nickel chloride hexahydrate $(0.2377 \mathrm{~g}$; $1 \mathrm{mmol}$ ) to $20 \mathrm{ml}$ ethanolic solution of mononuclear $\mathrm{Ni}(\mathrm{II})$ complex $(0.5634 \mathrm{~g} ; 1 \mathrm{mmol})$. The resulting mixture was heated under reflux for $4 \mathrm{~h} .{ }^{12,13}$. After refluxing, the resulting solution was filtered, washed thoroughly with ethanol and dried in a vacuum. After six days, the greenish brown solid complex was obtained.

\section{Synthetic route of heterobinuclear Schiff base metal complexes}

Hetero binuclear metal complex from mononuclear $\mathrm{Cu}$ (II) complex

The hetero binuclear $\mathrm{MM}_{1}(\mathrm{II})$ complex $(\mathrm{M}=$ $\mathrm{Cu} ; \mathrm{M}_{1}=\mathrm{Ni}$ ) was synthesized by slow addition of 20 $\mathrm{ml}$ ethanolic solution of nickel chloride hexahydrate

Table 2: Characteristic infrared spectral bands for Schiff base ligand(L) and its $\mathrm{Cu}(\mathrm{II})$ \& $\mathrm{Ni}(\mathrm{II})$ complexes

\begin{tabular}{ccccccc}
\hline S.No. Compounds & $v(\mathbf{O H})\left(\mathbf{c m}^{-1}\right)$ & $v(\mathbf{C}=\mathbf{N})\left(\mathbf{c m}^{-1}\right)$ & $v(\mathbf{C}-\mathbf{O})\left(\mathbf{c m}^{-1}\right)$ & $v(\mathbf{M}-\mathbf{O})\left(\mathbf{c m}^{-1}\right)$ & $v(\mathbf{M}-\mathbf{N})\left(\mathbf{c m}^{-1}\right)$ \\
\hline 1 & $\mathrm{~L}$ & 3423 & 1592 & 1438 & - & - \\
2 & $\mathrm{CuL}$ & - & 1505 & 1430 & 754 & 545 \\
3 & $\mathrm{NiL}$ & - & 1610 & 1436 & 550 & 500 \\
4 & $\mathrm{Cu}_{2} \mathrm{LCl}_{2}$ & - & 1610 & 1436 & 563 & 477 \\
5 & $\mathrm{Ni}_{2} \mathrm{LCl}_{2}$ & - & 1643 & 1435 & 667 & 500 \\
6 & $\mathrm{CuNiLCl}$ & - & 1629 & 1436 & 750 & 500 \\
7 & $\mathrm{NiCuLCl}$ & - & 1618 & 1438 & 748 & 490 \\
\hline
\end{tabular}


$(0.2377 \mathrm{~g} ; 1 \mathrm{mmol})$ to $20 \mathrm{ml}$ ethanolic solution of mononuclear $\mathrm{Cu}(\mathrm{II})$ complex $(0.5781 \mathrm{~g} ; 1 \mathrm{mmol})$. The resulting mixture was heated under reflux for 3 hrs ${ }^{12,13}$. After refluxing, the resulting solution was filtered, purified with ethanol and dried in a vacuum. After five days, the greenish blue solid complex was obtained.
Hetero binuclear metal complex from mononuclear $\mathrm{Ni}$ (II) complex

The hetero binuclear $\mathrm{M}_{1} \mathrm{M}(\mathrm{II})$ complex $\left(\mathrm{M}=\mathrm{Cu} ; \mathrm{M}_{1}=\mathrm{Ni}\right.$ ) was synthesized by slow addition of $20 \mathrm{ml}$ ethanolic solution of anhydrous copper chloride $(0.1345 \mathrm{~g} ; 1 \mathrm{mmol})$ to $20 \mathrm{ml}$ ethanolic solution of mononuclear $\mathrm{Ni}(\mathrm{II})$ complex $(0.5634 \mathrm{~g} ; 1 \mathrm{mmol})$. The resulting mixture was heated under reflux for

Table 3: Electronic spectral assignments for Schiff base ligand(L) and its $\mathrm{Cu}$ (II) \& $\mathrm{Ni}(\mathrm{II})$ complexes

\begin{tabular}{|c|c|c|c|c|}
\hline S.No. & Complex & $\lambda \max (\mathrm{nm})$ & Band assignment & Geometry of the complex \\
\hline \multirow[t]{2}{*}{1} & \multirow[t]{2}{*}{ L } & 220 & $\pi-\pi^{*}$ & \multirow[t]{2}{*}{-} \\
\hline & & 348 & $\mathrm{n}-\pi^{*}$ & \\
\hline \multirow[t]{4}{*}{2} & \multirow[t]{4}{*}{ CuL } & 230 & $\pi-\pi^{*}$ & \multirow[t]{4}{*}{ Square planar } \\
\hline & & 362 & $\mathrm{n}-\pi^{*}$ & \\
\hline & & 457 & $\mathrm{~L} \rightarrow \mathrm{M}$ charge transfer & \\
\hline & & 585 & ${ }^{2} \mathrm{~B} 1 \mathrm{~g} \rightarrow{ }^{2} \mathrm{~A} 1 \mathrm{~g}$ & \\
\hline \multirow[t]{5}{*}{3} & \multirow[t]{5}{*}{$\mathrm{NiL}$} & 256 & $\pi-\pi^{\star}$ & \multirow[t]{5}{*}{ Square planar } \\
\hline & & 368 & $\mathrm{n}-\pi^{\star}$ & \\
\hline & & 436 & $\mathrm{~L} \rightarrow \mathrm{M}$ charge transfer & \\
\hline & & 570 & ${ }^{1} A_{1 g} \rightarrow{ }^{1} A_{2 g}$ & \\
\hline & & 630 & ${ }^{1} A_{1 g} \rightarrow{ }^{1} B_{1 g}^{2 g}$ & \\
\hline \multirow[t]{4}{*}{4} & \multirow{4}{*}{$\mathrm{Cu}_{2} \mathrm{LCl}_{2}$} & 264 & $\pi-\pi^{\star}$ & \multirow[t]{4}{*}{ Square planar } \\
\hline & & 380 & $\mathrm{n}-\pi \delta^{*}$ & \\
\hline & & 460 & $\mathrm{~L} \rightarrow \mathrm{M}$ charge transfer & \\
\hline & & 570 & ${ }^{2} \mathrm{~B}_{1} \mathrm{~g} \rightarrow{ }^{2} \mathrm{~A}_{1} \mathrm{~g}$ & \\
\hline \multirow[t]{5}{*}{5} & \multirow[t]{5}{*}{$\mathrm{Ni}_{2} \mathrm{LCl}_{2}$} & 249 & $\pi-\pi^{*}$ & \multirow[t]{5}{*}{ Square planar } \\
\hline & & 382 & $\mathrm{n}-\pi^{\star}$ & \\
\hline & & 430 & $\mathrm{~L} \rightarrow \mathrm{M}$ charge transfer & \\
\hline & & 520 & ${ }^{1} A_{1 g} \rightarrow{ }^{1} A_{2 g}$ & \\
\hline & & 600 & ${ }^{1} \mathrm{~A}_{1 \mathrm{~g}} \rightarrow{ }^{1} \mathrm{~B}_{1 \mathrm{~g}}$ & \\
\hline \multirow[t]{5}{*}{6} & \multirow[t]{5}{*}{$\mathrm{CuNiLCl}_{2}$} & 270 & $\pi-\pi^{*}$ & \multirow[t]{5}{*}{ Square planar } \\
\hline & & 375 & $\mathrm{n}-\pi^{\star}$ & \\
\hline & & 460 & $\mathrm{~L} \rightarrow \mathrm{M}$ charge transfer & \\
\hline & & 560 & ${ }^{1} \mathrm{~A}_{1} \mathrm{~g} \rightarrow{ }^{1} \mathrm{~A}_{2} \mathrm{~g}$ & \\
\hline & & 647 & ${ }^{1} \mathrm{~A}_{1} \mathrm{~g} \rightarrow{ }^{1} \mathrm{~B}_{1} \mathrm{~g}$ & \\
\hline \multirow[t]{5}{*}{7} & \multirow[t]{5}{*}{$\mathrm{NiCuLCl}_{2}$} & 262 & $\pi-\pi^{*}$ & \multirow[t]{5}{*}{ Square planar } \\
\hline & & 347 & $n-\pi^{*}$ & \\
\hline & & 437 & $\mathrm{~L} \rightarrow \mathrm{M} / \mathrm{CT}$ & \\
\hline & & 534 & ${ }^{1} A_{1} g \rightarrow{ }^{1} A_{2} g$ & \\
\hline & & 615 & ${ }^{1} A_{1} g \rightarrow s B_{1} g$ & \\
\hline
\end{tabular}




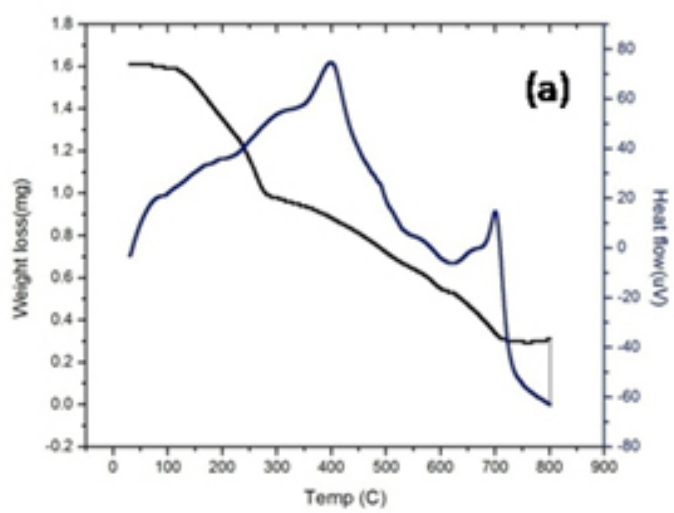

Fig. 2a: Thermogram of CuL

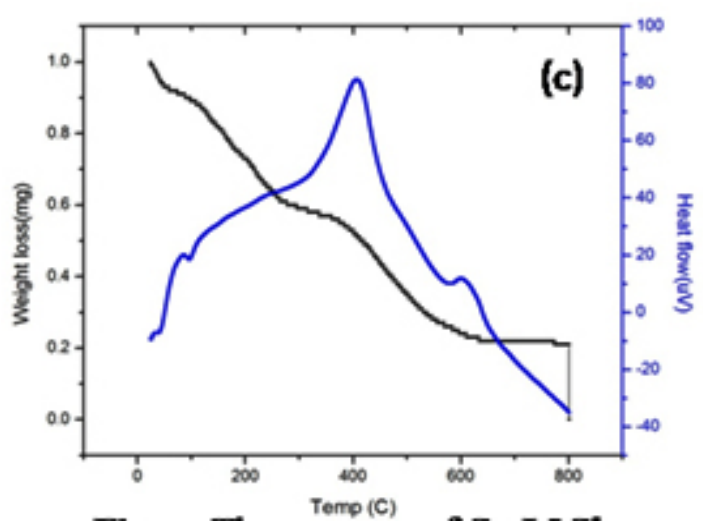

Fig. 2c: Thermogram of $\mathrm{Cu}_{2} \mathrm{~L}_{2} \mathrm{CL}_{2}$

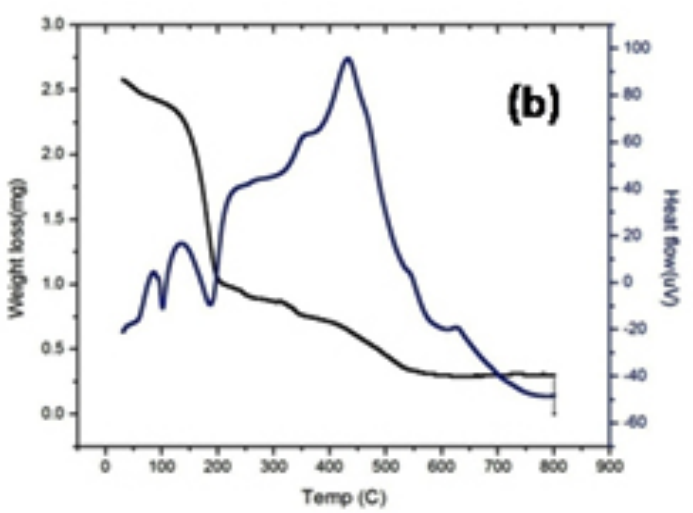

Fig. 2b: Thermogram of NiL

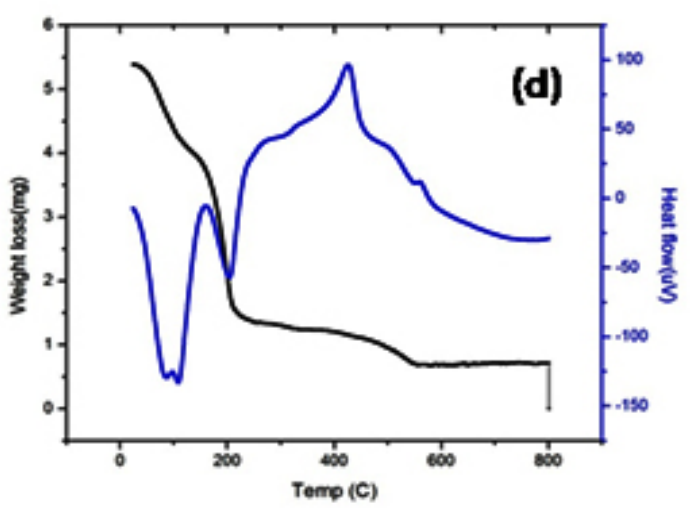

Fig. 2d: Thermogram of $\mathrm{Ni}_{2} \mathrm{LCL}_{2}$

Fig. 2 (a-d): Thermal Analyses (TGA/DTA) of Cu(II) \& Ni(II) complexes

Table 4: Thermal analysis data of Schiff base ligand(L) and its metal(II) complexes

\begin{tabular}{|c|c|c|c|}
\hline Complexes & $\begin{array}{l}\text { Temperature } \\
\text { range of } \\
\text { decomposition } \\
\left({ }^{\circ} \mathrm{C}\right)\end{array}$ & $\%$ of weight loss & Assignment \\
\hline \multirow[t]{2}{*}{ CuL } & $130-270$ & $30.45(30.66)$ & Loss of $5 \mathrm{Cl}$ \\
\hline & $360-780$ & $56.56(55.52)$ & Loss of $\mathrm{C}_{22} \mathrm{H}_{13} \mathrm{~N}_{2} \mathrm{O}$ with the formation of $\mathrm{CuO}$ \\
\hline \multirow[t]{2}{*}{ NiL } & $130-190$ & $30.75(30.92)$ & Loss of $5 \mathrm{Cl}$ \\
\hline & $305-750$ & $55.27(55.99)$ & Loss of $\mathrm{C}_{22} \mathrm{H}_{13} \mathrm{~N}_{2} \mathrm{O}$ with the formation of $\mathrm{NiO}$ \\
\hline \multirow{2}{*}{$\mathrm{Cu}_{2} \mathrm{LCl}_{2}$} & $120-260$ & $31.80(34.38)$ & Loss of 7 chloride ions \\
\hline & $410-790$ & $40.36(42.80)$ & Loss of $\mathrm{C}_{22} \mathrm{H}_{13} \mathrm{~N}_{2}$ with the formation of $2 \mathrm{CuO}$ \\
\hline \multirow[t]{2}{*}{$\mathrm{Ni}_{2} \mathrm{LCl}_{2}$} & $145-215$ & $49.46(50.93)$ & Loss of $\mathrm{C}_{12} \mathrm{H}_{4} \mathrm{Cl}_{6}$ \\
\hline & $430-790$ & 23.71(27.32) & Loss of $\mathrm{C}_{10} \mathrm{H}_{9} \mathrm{~N}_{2} \mathrm{Cl}$ with formation of $\mathrm{NiO}$ \\
\hline \multirow[t]{2}{*}{$\mathrm{CuNiLCl}_{2}$} & $130-260$ & $24.67(27.01)$ & Loss of 6 chloride ions \\
\hline & $370-760$ & $46.12(48.04)$ & $\mathrm{C}_{22} \mathrm{H}_{13} \mathrm{~N}_{2} \mathrm{Cl}$ with the formation of $\mathrm{CuO}$ and $\mathrm{NiO}$ \\
\hline \multirow[t]{2}{*}{$\mathrm{NiCuLCl}_{2}$} & $140-200$ & $34.37(34.61)$ & Loss of 7 chloride ions \\
\hline & $460-780$ & $41.08(43.09)$ & Loss of $\mathrm{C}_{22} \mathrm{H}_{13} \mathrm{~N}_{2}$ with formation of $\mathrm{NiO}$ and $\mathrm{CuO}$ \\
\hline
\end{tabular}


3 h. ${ }^{12,13}$. After refluxing, the resulting solution was filtered and washed with ethanol. The dark green solid product obtained was dried in vacuo.

\section{Pharmacological applications of synthesized} compounds

\section{Antibacterial assay}

The synthesized Schiff base and their metal complexes were screened for their antibacterial properties of the disc agar diffusion method in DMF solvent against $S$. aureus, B. subtilis (Gram-positive bacteria), E. coli and P. bacilli (Gramnegative bacteria). The antibiotic Streptomycin was used as the standard reference in the case. The tested compounds were dissolved in ethanol to get concentration of $10,20,30$ and $40 \mathrm{mg} / \mathrm{L}$. The test was performed on medium potato dextrose agar contains infusion of $200 \mathrm{~g}$ potatoes, $6 \mathrm{~g}$ dextrose and $15 \mathrm{~g}$ agar. Uniform size filter paper discs (three disks per compound) were impregnated by equal volume from the specific concentration of dissolved tested compounds and carefully placed on incubated agar surface. After incubation for $36 \mathrm{~h}$ at $27^{\circ} \mathrm{C}$, inhibition of the organism which evidenced by clear zone surrounds each disk was measured and used to calculate mean of inhibition zones ${ }^{14}$.

$\%$ Activity Index =

Zone of Inhibition by test compound (diammeter)

Zone of Inhibition by standard (diammeter) $* 100$

\section{In-vitro anticancer activity}

An anticancer activity of the mono, homo and hetero binuclear Schiff base $\mathrm{Cu}$ (II) and $\mathrm{Ni}(\mathrm{II})$ complexes was performed in the MCF-7 culture medium. Test samples in triplicates were added to the cells. After incubation at $37^{\circ} \mathrm{C}$ for $18 \mathrm{~h}$. MTT was added in all the wells and incubated for $4 \mathrm{hrs}$. After incubation, DMSO was added in the wells and read at $570 \mathrm{~nm}$ using a photometer. Cytotoxicity and cell viability was calculated by the following formula.

Cytotoxicity $=[($ Control-Treated $) /$ control $]{ }^{*} 100$

Cell viability $=($ Treated $/$ Control $) * 100$.

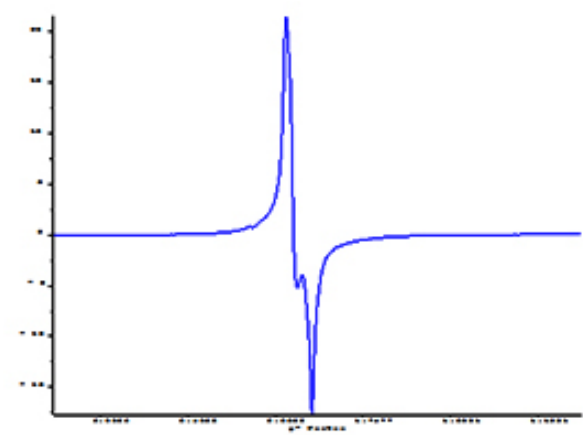

Fig. 3b: EPR spectrum of $\mathrm{Cu}$
Fig. 3a: EPR spectrum of CuL

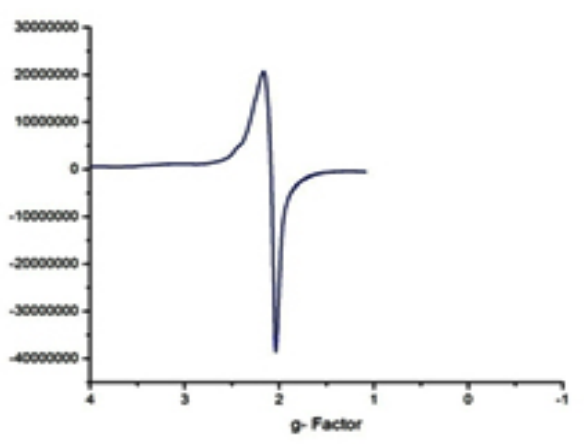

Fig. 3c: EPR spectrum of CuNiLCL ${ }_{2}$

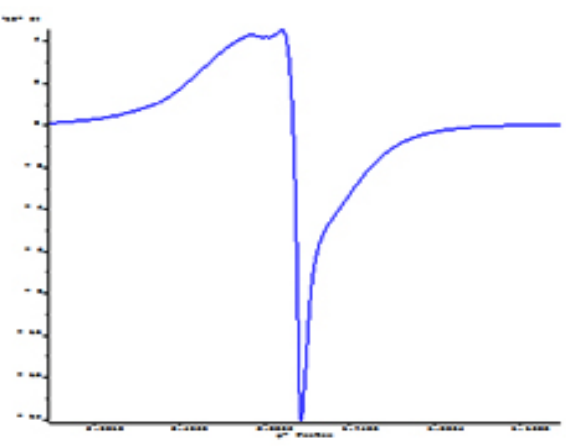

Fig. 3(a-d): EPR spectrum of $\mathrm{Cu}(\mathrm{II})$ complexes 


\section{RESULTS AND DISCUSSION}

All the metal complexes show molar conductivities in the range of $13.64-14.84 \mathrm{ohm}^{-1} \mathrm{~cm}^{2}$ $\mathrm{mol}^{-1}$ (Table 1) in $10^{-3} \mathrm{M}$ ethanolic solution analogous to non electrolytes. The neutrality of the complexes can be correlated by the deprotonated nature of the ligand with most complexes ${ }^{15}$.

\section{IR spectral studies}

IR spectral datas of ligand and its metal complexes make known the involvement of coordination sites in chelation (Table 2). The free ligand showed a characteristic band at $1592 \mathrm{~cm}^{-1}$ and $1438 \mathrm{~cm}^{-1}$ is assigned to azomethine $(\mathrm{C}=\mathrm{N})$ and $\mathrm{C}-\mathrm{O}$ group respectively, which shifted to either higher or lower wavenumber upon coordination in all the complexes supporting the coordination through azomethine nitrogen and phenoxo oxygen atoms ${ }^{16-20}$. A sharp vibrational band positioned at $3423 \mathrm{~cm}^{-1}$ is correspond to $-\mathrm{OH}$ group belonging to the 3, 5-dichloro-2-hydroxyacetophenone, which disappear in complexes confirms deprotonation of $-\mathrm{OH}$ group and coordination of oxygen to the metal. The stronger bands observed in the region 490-545 $\mathrm{cm}^{-1}$ and $550-754 \mathrm{~cm}^{-1}$ in metal complexes, which has been assigned to $\mathrm{M}-\mathrm{N}$ and $\mathrm{M}-\mathrm{O}$ stretching frequencies respectively. IR data confirm the $\mathrm{Cu}$ (II) \& $\mathrm{Ni}(\mathrm{II})$ metal atom binding together with both $\mathrm{O}$ and $\mathrm{N}$ donor groups of the Schiff base ligand and support the tentative structure of the complexes.

\section{Electronic spectral studies}

The electronic spectral characteristics $(230-800 \mathrm{~nm})$ of the ligand and complexes in ethanol are given in Table 3. The electronic spectrum of the ligand in ethanol exhibits two bands in the range $220-350 \mathrm{~nm}$ due to $\pi \rightarrow \pi^{\star}$ and $n \rightarrow \pi^{\star}$ transitions ${ }^{21-23}$. The high intensity band obtained at $220 \mathrm{~nm}$ is assigned to intraligand charge transfer transition, $\pi \rightarrow \pi^{*}$ of benzene ring ${ }^{24-26}$. The medium energy band at $348 \mathrm{~nm}$ was assigned to $\mathrm{n} \rightarrow \pi^{*}$ transition of the azomethine group ${ }^{27}$. The corresponding azomethine band showed a slight shift to longer wavelength on going from ligand to complex, indicating coordination of ligand to metal through the azomethine group. A moderately intensive band observed in the region of $430-460$ $\mathrm{nm}$ is attributable to the ligand $\rightarrow \mathrm{M}$ charge transfer transitions in all the complexes. The mononuclear $\mathrm{Cu}$ (II) complex exhibited a band at $585 \mathrm{~nm}$ assigned to ${ }^{2} \mathrm{~B}_{1} \mathrm{~g} \rightarrow{ }^{2} \mathrm{~A}_{1} \mathrm{~g}$ transition, suggesting square planar geometry around $\mathrm{Cu}(\mathrm{II})$ center $^{16}$. The electronic spectrum of mononuclear $\mathrm{Ni}(\mathrm{II})$ complex exhibits two bands at 570 and $630 \mathrm{~nm}$ that was assigned to ${ }^{1} \mathrm{~A}_{1} \mathrm{~g} \rightarrow{ }^{1} \mathrm{~A}_{2} \mathrm{~g}$ and ${ }^{1} \mathrm{~A}_{1} \mathrm{~g} \rightarrow{ }^{1} \mathrm{~B}_{1} \mathrm{~g}$ transition respectively, consistent with square planar geometry ${ }^{28}$. Homo binuclear $\mathrm{Cu}$ (II) complex exhibited one absorption band at $570 \mathrm{~nm}$, which was attributed to ${ }^{2} \mathrm{~B}_{1} \mathrm{~g} \rightarrow{ }^{2} \mathrm{~A}_{1} \mathrm{~g}$ transition indicating the square planar geometry. Homo binuclear Ni(II) complex exhibits two absorption bands, which fall at 520 and $600 \mathrm{~nm}$ attributed to ${ }^{1} \mathrm{~A}_{1} \mathrm{~g} \rightarrow{ }^{1} \mathrm{~A}_{2} \mathrm{~g}$ and ${ }^{1} \mathrm{~A}_{1} \mathrm{~g} \rightarrow{ }^{1} \mathrm{~B}_{1} \mathrm{~g}$ transitions

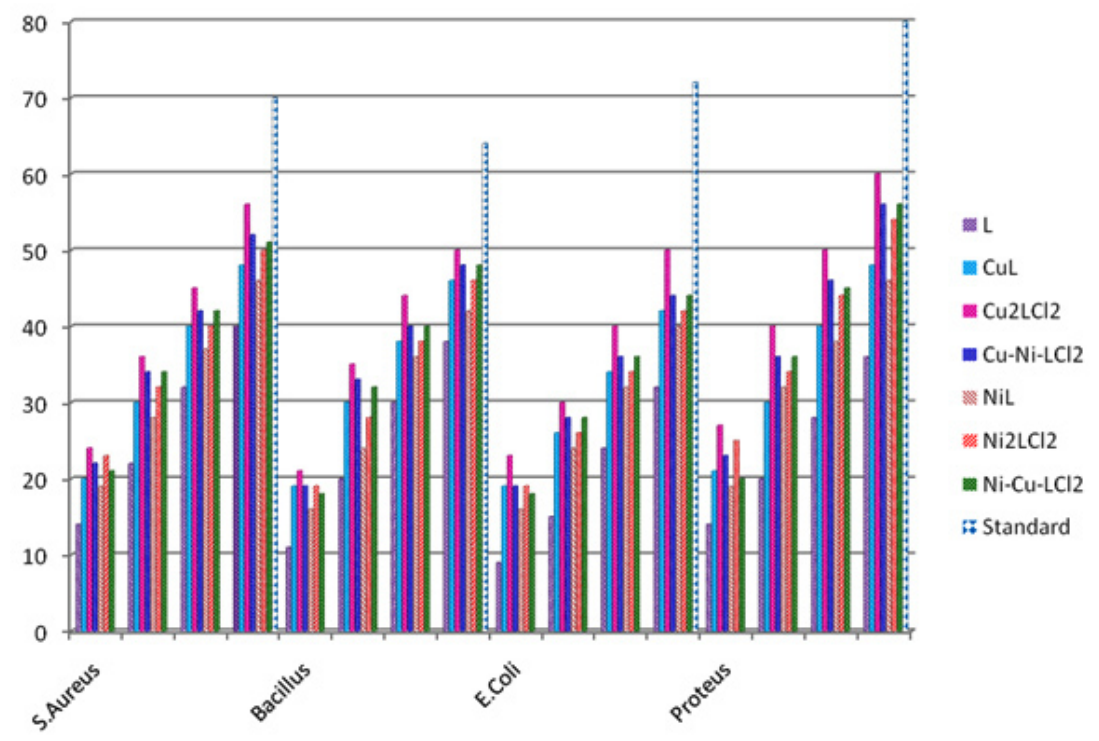

Fig. 4: Antibacterial activity of Schiff base ligand and its metal complexes 
respectively consistent with that of the square planar geometry. The electronic absorption spectra of the hetero binuclear complexes show absorptions at 560 and $647 \mathrm{~nm}$, which may be recognized to ${ }^{1} \mathrm{~A}_{1} \mathrm{~g} \rightarrow{ }^{1} \mathrm{~A}_{2} \mathrm{~g}$ and ${ }^{1} \mathrm{~A}_{1} \mathrm{~g} \rightarrow{ }^{1} \mathrm{~B}_{1} \mathrm{~g}$ transitions for $\mathrm{Ni}(\mathrm{II})$. The band at $560 \mathrm{~nm}$, which may be an overlapping region with that of the $\mathrm{Ni}(\mathrm{II})$ ion, may also be due to ${ }^{2} \mathrm{~B}_{1} \mathrm{~g} \rightarrow{ }^{2} \mathrm{~A}_{1} \mathrm{~g}$ transition of the $\mathrm{Cu}(\mathrm{II})$ ion in the hetero binuclear complexes. These values are well within the range reported for square planar complexes.

\section{${ }^{1} \mathrm{H}$ NMR spectral studies}

To elucidate the structure and nature of ligand, the 1HNMR spectra of the Schiff base ligand was recorded in $\mathrm{CDCl}_{3}$ using TMS as the reference compound at room temperature (fig. 1). The multiplet at $\delta=6.6-7.6 \mathrm{ppm}$ correspond to aromatic protons $^{29}$. The singlet peak appears at $\delta=12.738$ $\mathrm{ppm}$ is attributed to the phenolic - $\mathrm{OH}$ group present and additional peak appear in the range of $\delta=2.402 \mathrm{ppm}$ is attributed to the methyl protons of the ligand ${ }^{30}$.

\section{Cyclic voltammetry}

The electro chemical behavior of metal complexes was studied by cyclic voltammetry in DMSO containing TBAP as supporting electrolyte between the range of 2.0 to $-2.0 \mathrm{~V}$. The electrochemical data such as cathodic peak potential $\left(E_{p c}\right)$, anodic peak potential $\left(E_{p a}\right)$, peak separation $\left(E_{p}\right)$ and redox potential, $E_{1 / 2}$ are given in Table 4. The mononuclear $\mathrm{Cu}(\mathrm{II})$ and $\mathrm{Ni}(\mathrm{II})$ complexes shows cathodic peak potential at, $\mathrm{E}_{\mathrm{pc}}=-0.4$ and $-0.5 \mathrm{~V}$, with an associated anodic peak at, $\mathrm{E}_{\mathrm{pa}}=-0.2$ and $-0.1 \mathrm{~V}, \Delta \mathrm{E}_{\mathrm{p}}=200$ and 400 and $E_{1 / 2}=-0.35$ and -0.3 . Since $\Delta E_{p}$ value indicates a quasireversible one electron transfer redox behavior mononuclear $\mathrm{Cu}(\mathrm{II})$ and $\mathrm{Ni}(\mathrm{II})$ complexes ${ }^{31}$.

$\mathrm{Cu}(\mathrm{II}) \leftrightarrow \mathrm{Cu}(\mathrm{I})$

$\mathrm{Ni}(\mathrm{II}) \leftrightarrow \mathrm{Ni}(\mathrm{I})$

Table 5: EPR spectral parameters of Schiff base $\mathrm{Cu}(\mathrm{II}) \& \mathrm{Ni}(\mathrm{II})$ complexes

\begin{tabular}{lccccc}
\hline S.No Complex & $\mathbf{g} \|$ & $\mathbf{g} \perp$ & $\Delta \mathbf{g}$ & $\mathbf{G}$ \\
\hline 1. & $\mathrm{CuL}$ & 2.2342 & 2.1026 & 0.1316 & 2.28 \\
2. & $\mathrm{Cu}_{2} \mathrm{LCl}_{2}$ & 2.2301 & 2.1026 & 0.1274 & 2.2417 \\
3. & $\mathrm{CuNiLCl}_{2} 2.1781$ & 2.0453 & 0.1328 & 3.9315 \\
4. & $\mathrm{NiCuLCl}$ & 2.1781 & 2.0526 & 0.1255 & 3.3859 \\
\hline
\end{tabular}

The $\Delta \mathrm{E}_{\mathrm{p}}$ and $\mathrm{E}_{1 / 2}$ values shows that all the homo and hetero binuclear $\mathrm{Cu}$ (II) \& Ni(II) complexes exhibit two one electron anodic and cathodic responses $^{32}$ and the processes are expressed as follows:

$$
\begin{aligned}
& \mathrm{Cu}^{\text {II }} \mathrm{Cu}^{\text {II }} \leftrightarrow \mathrm{Cu}^{\text {II }} \mathrm{Cu}^{\prime} \leftrightarrow \mathrm{Cu}^{\prime} \mathrm{Cu}^{\prime} \\
& \mathrm{Ni}^{\mathrm{II}}+\mathrm{Ni}^{\mathrm{II}} \leftrightarrow \mathrm{Ni}^{\mathrm{II}} \mathrm{Ni}^{\prime} \leftrightarrow \mathrm{Ni}^{\prime} \mathrm{Ni}^{\prime} \\
& \mathrm{Cu}^{\mathrm{II}} \mathrm{Ni}^{\mathrm{II}} \leftrightarrow \mathrm{Cu}^{\mathrm{II}} \mathrm{Ni}^{\prime} \leftrightarrow \mathrm{Cu}^{\prime} \mathrm{Ni}^{1}
\end{aligned}
$$

\section{Thermal analyses (TG/DTA)}

To determine the thermal stability and chemical composition of Schiff base metal complexes, TG and DT analysis has been carried out in a temperature range of $20-800^{\circ} \mathrm{C} / \mathrm{min}$ and was shown in Figure 2(a-d). The thermal behaviour of all the Schiff base $\mathrm{Cu}$ (II) \& Ni(II) complexes was almost similar. Mononuclear $\mathrm{Cu}$ (II) complex decomposed into two stages. The first stage, at 130-270 ${ }^{\circ} \mathrm{C} / \mathrm{min}$, corresponds to the loss of five chloride ions (exp.30.45\% ; calcd. $30.66 \%$ ). The process of elimination is also confirmed by DTA curve at $220^{\circ} \mathrm{C}$. In the second stage, it loses $\mathrm{C}_{22} \mathrm{H}_{13} \mathrm{~N}_{2} \mathrm{O}$ (exp. 56.56 , calcd. $55.52 \%$ ) with formation of metal oxide (CuO) 33, 34 at $360-780{ }^{\circ} \mathrm{C} / \mathrm{min}$ and is further conformed by DTA curve at $640{ }^{\circ} \mathrm{C}$. $\mathrm{Ni}$ (II) complex degraded in two steps. The first step resulted in mass loss of $30.75 \%$ (calcd. $30.92 \%$ ) corresponding to the loss of five chloride ions within the temperature range $130-190{ }^{\circ} \mathrm{C}$. This process of elimination is also indicated by $157^{\circ} \mathrm{C}$ on DTA curve. The second step involved weight loss of $55.27 \%$ (calcd. 55.99 $\%$ ) corresponding to the removal of the remaining part of the ligand (temperature range $305-750{ }^{\circ} \mathrm{C}$ ) leaving metal oxide (NiO) with DTA curve at $630^{\circ} \mathrm{C}$. The overall weight losses for the complexes are in good agreement with the proposed formula obtained by elemental analyses, IR and UV data's. In the same way decomposition of homo and hetro binuclear complexes are given the Table 4. From the results, it is well evident that the hetero binuclear complex decomposes at a higher temperature than compared to mononuclear and homo binuclear complexes.

\section{EPR spectra}

The X-band EPR spectra of mononuclear, homo and hetero-binuclear $\mathrm{Cu}(\mathrm{II})$ complexes were recorded at room temperature using DPPH as a reference (Figure 3(a-d)). The corresponding data are given in the Table 5 . The $g$ values observed 
for mononuclear $\mathrm{Cu}(\mathrm{II})$ complex $\mathrm{g} \|=2.2342$, $g^{\perp}=2.1026, G=2.28$. The $g l l$ and $g \perp$ values are greater than 2.04 which confirmed the existence of unpaired electron in the $\mathrm{dx}^{2}-\mathrm{y}^{2}$ orbital corresponds to square planar geometry around the $\mathrm{Cu}(\mathrm{II})$ center ${ }^{35}$ is an important function for indicating covalent character of $\mathrm{M}-\mathrm{L}$ bonds ${ }^{36}$. For ionic character, $\mathrm{g} \|>2.30$ while in covalent character $\mathrm{g} \|<2.30$. In the present compounds, the g $\mid<2.30$ indicating appreciable covalent character for $M-L$ bond. The exchange interaction between copper centers are measured by the expression $G=(q \|-2) /\left(q^{\perp}-2\right)$. The calculated $G$ values for these complexes are in the range 2.28-3.9315 which predicts the weak exchange interaction.

\section{Antibacterial screening of Schiff base and its complexes}

In recent times pharmaceutical industries are looking for synthesizing the alternative compounds which act as a drug. At present much consideration has been focussed on the synthesis of new metal complexes and the evaluation of these agents for antibacterial activity ${ }^{37}$. S. aureus, B. substils (Grampositive) and E. coli, P.bacilli (Gram-negative) are the general bacterias that are found in the contaminated wound. The synthesized homo and hetero binuclear complexes were tested against Gram positive and Gram negative stains at different concentrations like
$10,20,30$ and $40(\mu \mathrm{g} / \mathrm{mL})$ which are compared with control (Streptomycin) (Figure 4). From the figure, it is well evident that homo binuclear Schiff base copper(II) complexes have higher antibacterial activity against both Gram-positive and Gram-negative bacteria stains. The variation in the effectiveness of different compounds against different organisms depends either on the impermeability of the cells of the microbes or on divergence in ribosome of microbial cells. Current studies reveal that the metal ions with high atomic radius and electronegativity in their metal complexes exhibit high antimicrobial activity. In particular the complexes showed excellent activity against $\mathrm{E}$. coli which is due to the differences in the cell wall structure. The cell wall of the gram-positive bacteria are made of a thick layer of peptidoglycan, consisting of linear polysaccharide chains leading to difficult penetration compared to the gram-negative bacteria where the cell wall possesses thinner layer of peptidoglycan. The increased antibacterial activity of the metal complexes suggests that the chelation could facilitate the ability of a complex to cross a cell membrane and can be explained by Tweedy's chelation theory ${ }^{38}$. Chelation considerably reduces the polarity of the metal ion because of partial sharing of its positive charge with donor groups and possible electron delocalization over the whole chelate ring. Such a chelation could enhance the lipophilic character of the central metal atom, which

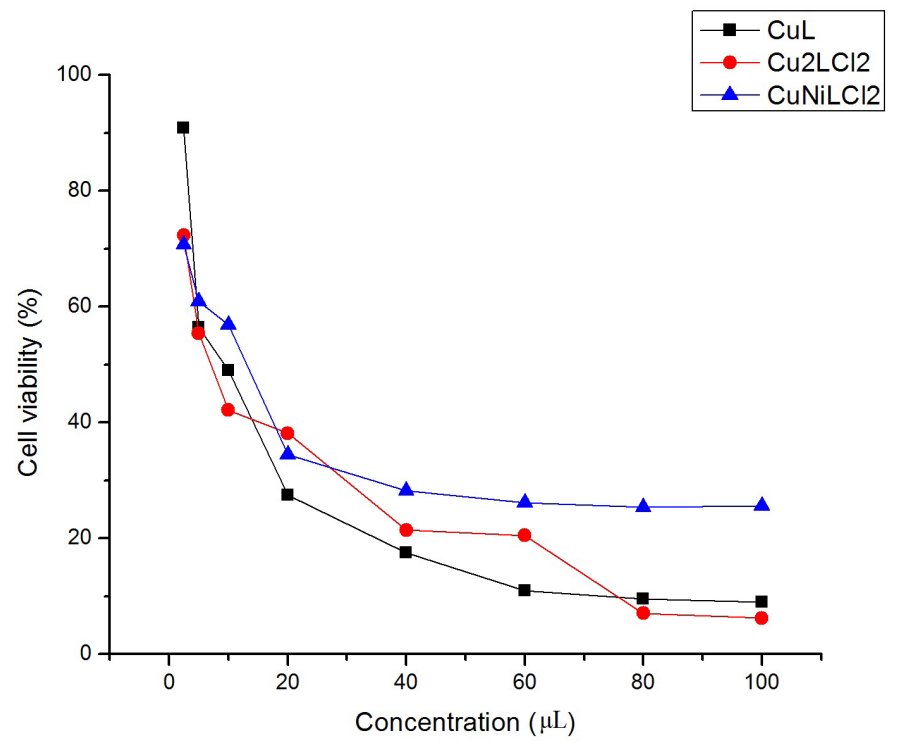

Fig. 5: \% growth inhibition of MCF-7 cell line by synthesized compounds 
subsequently favors its permeation through the lipid layer of the cell membrane.

\section{In-vitro Cytotoxic activity}

The anticancer activity of the synthesized metal complexes was studied by treating it with MCF-7cell line (human breast cancer cell) and read at $570 \mathrm{~nm}$ using a photometer by applying MTT assay. The results were analyzed by cell viability curves, expressed with $\mathrm{IC}_{50}$ values in the studied concentration range of $2.5-100 \mu \mathrm{g} / \mathrm{mL}$ (Figure $5)$. The MTT cell proliferation assay has been widely accepted as a reliable way to measure the cell propagation rate ${ }^{39}$. The result showed that the complexes inhibited the growth of MCF-7 cells in a dose-dependent manner. In comparision the highest level of cytotoxic activity was observed in homo-binuclear $\mathrm{Cu}(\mathrm{II})$ complex $\left(\mathrm{IC}_{50}=7.3789\right)$. The results indicate that these complexes have beneficial features for potential anticancer agents.

\section{CONCLUSION}

Schiff base and its mononuclear, homo and hetero-binuclear metal complexes have been synthesized successfully and characterized by various physico chemical methods such as molar conductance, FT-IR, UV-Vis, 1HNMR, cyclic voltammetry, thermal analysis and EPR. All the metal complexes are square planar environment which was confirmed by electronic and EPR spectral data. The cyclic voltammetry result supported that the mononuclear complexes exhibit one step one electron transfer, whereas binuclear metal complexes exhibit two steps one electron transfer and quasi-reversible in nature. From thermal analysis, it was concluded that binuclear metal complexes were more stable than mononuclear metal complexes. From the result of antibacterial activity test, we conclude that the hetero-binuclear $\mathrm{Cu}$ (II) complex plays an effective role in improving the bioactivity. The anticancer activity result shows that homo binuclear $\mathrm{Cu}$ (II) complex has high cytotoxicity.

\section{REFERENCES}

1. Rosenberg, B.; VanCamp, L.; Trosko, J.E.; Mansour, V. H.; Nature, 1969, 222(5191), 385386.

2. Jungwirth, U.; Kowol, C. R.; Keppler, B. K.; Hartinger, C. G.; Berger, W.; Heffeter, P.; Liebert, M. A.; Inc., publishers, 2011, 15(4), 1085-127.doi:10.1089/ars.2010.3663.

3. Sinn, E.; Harris, C. M.; Coord. Chem. Rev., 1969, 4, 4391-4422.

4. Kuby, S. A.; Mechanism of Enzyme Action; CRC Press: Boca Raton, FL, 1990.

5. Trudu, F.; Amato, F.; Va hara, P.; Pivetta, T.; Peña-Méndez, E. M.; Havel, J.; J. App. Biomed., 2015, 13, 79-103.

6. Tisato, F.; Marzano, C.; Porchia, M.; Pellei, M.; Santini, C.; Med. Res. Rev., 2010, 30, 708749.

7. Kim, A.Y.; Seok, W.K.; Dong, Y.; Yun, H.; Inorg. Chim. Acta, 2001,319, 194.

8. Ramachandraiah, A.; Sarojini, T.; Laxma reddy, K.; Polyhedron, 1990, 9, 1703-1708.

9. Zacharias, P. S.; Ramachandraiah, A.; Polyhedron, 1985, 4, 1013-1017.

10. Hamil, A. M.; Abdelkarem, M.; Hemmet, M.;
El-ajaily, M. M.; J. ChemTech Res., 2012, 4, 682-685.

11. Al-Shaalan, N. H.; Molecules, 2011, 16, 86298645.

12. Vidal, M.; Rizzardi, G.; Vigato, P. A.; Casellato, U.; Kida, S.; Okawa, H.; Inorg. Chimica Acta, 1979, 34, 19-24.

13. Fenton, D. E.; Gayda, S. E.; Casellato, U.; Vidali, M.; Vigato, P. A.; Inorg. Chim. Acta, 1978, 27, 9-14.

14. Chohan, Z. H.; Supuran, C. T.; Scozzafava, A.; J. Enzyme Inhib. Med. Chem., 2004, 19(1), 79-84.

15. Geeta, B.; Shravankumar, K.; Muralidhar Reddy, P.; Ravikrishna, E.; Sarangapani, M.; Krishna Reddy, K.; Ravinder, V.; Spectrochim. Acta Part A, 2010, 77, 911-915.

16. Sharma, R. K.; Sing, R.V.; Tandon, J. P.; J. Inorg. Nucl. Chem, 1980, 42, 1382-1384.

17. Raman, N.; Sobha, S.; Spectrochim. Acta Part A, 2012, 85, 223-234.

18. Zhang, J.; Braunstein, P.; Welter, R.; Inorg. Chem, 2004, 43, 4172-4177.

19. Dutta, B.; Bag, P.; Adhikary, B.; Florke, U.; Nag, 
K.; J. Org. Chem., 2004, 69(16), 5419-5427.

20. Pattanayak, P.; Pratihar, J.L.; Patra, D.; Brandão, P.; Mal, D.; Felix, V.; Polyhedron, 2013, 59, 23-28.

21. Pattanayak, P.; Pratihar, J.L.; Patra, D.; Her Lin, C.; Brandão, P.; Mal, D.; Felix, V.; J. Coord. Chem., 2013, 66, 568-579.

22. Anbu, S.; Kamalraj, S.; Varghese, B.; Muthumary, J.; Kandaswamy, M.; Inorg. Chem., 2012, 51, 5580-5592.

23. Fekri, R.; Shaabani, B.; J. Appl. Environ. Biol. Sci., 2013, 3, 75-78.

24. MacLachlan, M. J.; Park, M. K.; Thompson, L. K.; Inorg. Chem, 1996, 35, 5492-5499.

25. Nagakavitha, D.; Hussainreddy, K.; Int J Pharm Bio Sci., 2014, 5(4), 294-304.

26. Tas, E.; Kilic, A.; Konak, N.; Yilmaz, I.; Polyhedron, 2008, 27, 1024-1032.

27. Rosenthal, M. F.; J. Chem. Educ., 1973, 50, 331-335.

28. Thomas, M.; Nair, M.K.M.; Radhakrishnan, R.K.; Synth.React.Inorg. Met.Org, 1995, 25, 471-479.

29. Silverstein, R. M.; Bassler, C. G.; Morril, T. C.; Spectrophotometric Identification of Organic Compound, 5th edn., New York, Wiley, 1991.
30. Breitmaier, E.; Structure Elucidation by NMR in Organic Chemistry, United Kingdom, John Wiley \& Sons, 2002.

31. Raman, N.; Ravichandran, S.; Thangaraja, C.; J. Chem. Sci., 2004, 116, 215-219.

32. Anupama, B.; Padmaja, M.; GyanaKumari, C.;. E-Journal of Chemistry, 2012; 9(1), 389400.

33. Nakamoto, K.; Infrared and Raman spectra of inorganic and coordination compounds, wiley, 3rd edn., New York, 1997.

34. El- Boraey, H. A.; Ayad, M. I.; Int.J. ChemTech Res, 2014, 6(1), 266-275.

35. Prabhumirashi, L. S.; Khoje, J. K.; Indian J Chem, 2004, 43A, 299-302.

36. Shakir, M.; Abbasi, A.; Khan, A. U.; Khan, S. .N.; Spectrochim. Acta Part A, 2011, 78, 2935.

37. Wei, Q. Y.; Xiong, J. J.; Jiang, H.; Zhang, C.; Ye, W.; Int. J. Food Microbio., 2011, 150, 164170.

38. Tweedy, B. G.; Phytopathology, 1964, 55, 910914.

39. Marques, M. P. M.; Gira, T.; Lima, M. C. P. D.; Gameiro, A.; Pereira, E.; Garcia, P.; Biochim. Biophys. Acta, 2002, 1589, 63-70. 